\title{
Chapter 10 \\ Carbon Stocks from Peat Swamp Forest and Oil Palm Plantation in Central Kalimantan, Indonesia
}

\author{
Nisa Novita, J. Boone Kauffman, Kristell Hergoualc'h, Daniel Murdiyarso, \\ Dede Hendry Tryanto, and Joni Jupesta
}

\begin{abstract}
Conserving high carbon density tropical peat forests is one of the most cost-efficient strategies for climate change mitigation at national and global levels. Over past decades, large areas of tropical peat forests have been converted to oil palm plantation in Indonesia resulting in significant carbon emissions into the atmosphere. Here, we quantified the ecosystem carbon stocks in a total of six sites: two primary peat swamp forest sites, one secondary peat swamp forest site, and three young oil palm plantation sites in Tanjung Puting, Central Kalimantan, Indonesia. We further determined potential carbon emissions from vegetation change due to peat swamp forest conversion to oil palm plantation. The mean total ecosystem carbon stock of primary and secondary peat swamp forests were $1770 \pm 123 \mathrm{Mg} \mathrm{C} /$ ha and $533 \pm$ $49 \mathrm{Mg} \mathrm{C} / \mathrm{ha}$, respectively. In contrast, the mean carbon stock of oil palm plantations was $759 \pm 87 \mathrm{Mg} \mathrm{C} / \mathrm{ha}$ or $42 \%$ of peat swamp forests. The ratio of the aboveground to belowground $\mathrm{C}$ stock was highest in secondary forest with an estimated value of 0.48 , followed by primary forest at 0.19 and oil palm plantation at 0.04 . Using a stock difference approach, we estimated potential carbon emissions from vegetation change resulting from the conversion of primary peat swamp forest to oil palm plantation
\end{abstract}

The original version of this chapter was revised: This chapter has been changed to open access under a CC BY 4.0 license. The correction to this chapter is available at https://doi.org/10.1007/ 978-3-030-55536-8_16

N. Novita $(\varangle) \cdot$ K. Hergoualc'h $\cdot$ D. Murdiyarso $\cdot$ D. H. Tryanto

Center for International Forestry Research, Jalan CIFOR, Situgede Sindang Barang, Bogor Barat 16680 , Indonesia

e-mail: nisa.novita.278@gmail.com

N. Novita · J. B. Kauffman

Oregon State University, Nash Hall, 2820 SW Campus Way, Corvallis, OR 97331, USA

D. H. Tryanto

Badan Restorasi Gambut, Gedung Graha Mandiri Lt. 21, Jl. Imam Bonjol No. 61, Menteng,

Jakarta Pusat 10310, Indonesia

J. Jupesta

PT. SMARt Tbk., SMART Research Institute, Jln Sukarno Hatta No 19, Pekanbaru, Riau 28294, Indonesia

R. Djalante et al. (eds.), Climate Change Research, Policy and Actions in Indonesia,

Springer Climate, https://doi.org/10.1007/978-3-030-55536-8_10 
of $640 \pm 114 \mathrm{Mg} \mathrm{CO}_{2} /$ ha. Finally, while restoring peatlands is important, avoiding peat conversion is imperative for Indonesia's climate change mitigation effort.

Keywords Tropical peat forest $\cdot$ Land-use change $\cdot$ Oil palm $\cdot$ Indonesia $\cdot$ Climate change mitigation

\section{Introduction}

Tropical peat swamp forests provide a broad array of important ecological functions and environmental services (Page et al. 2006). This ecosystem is known as a biodiversity hotspot supporting the existence of endemic and endangered flora and fauna (Posa et al. 2011). Tropical peat swamp forests are imperative for the socioeconomics of local communities, as resource for food, shelter, plant-based medicine, and cultural activities at local and global scale (Hergoualc'h et al. 2016). They also exert hydrological controls on water flow during wet and dry seasons (Wösten et al. 2006). In addition, the prominent role of tropical peatlands as carbon (C) reservoir and sink has been described in many scientific studies (Page et al. 2011; Murdiyarso et al. 2009; Yu et al. 2011; Warren et al. 2017). Approximately 84\% of peat carbon in Southeast Asia is found in Indonesia (Page et al. 2011) which equals to $18 \%$ of volume peat globally (Gumbricht et al. 2017), where extensive deforestation and degradation of peat swamp forests has occurred since the 1990s.

Recently, a half of tropical peat swamp ecosystem have been converted to managed plantation (particularly oil palm (Elaeis guineensis Jacq.) at smallholders and industrial scales, then followed by logged-over areas (Miettinen et al. 2015). In addition, fires emissions during land preparation and peat drainage result in high greenhouse gas emissions to the atmosphere (Langner and Siegerts 2009; Saharjo 2007). Currently, Indonesia is extensively avoiding peat conversion by extending moratorium on the conversion of peatland, rewetting peatlands, restoring degraded peatlands, and improving socioeconomic or community livelihood. Thus, reducing emissions from peat swamp forest deforestation is important relative to the commitment to reduce national emissions by $497 \mathrm{MtonCO}_{2} \mathrm{e}$ from forestry and land-use change sector. Including peat swamp forest conservation and restoration as main activity to achieve national NDC target is a promising step to cut land-based emissions by an estimated $29 \%$ compared to the business as usual scenario by 2030 .

Given that tropical peat swamp forests have been recognized as having exceptionally high carbon stocks coupled with rapid rates of deforestation in the past, it is important to quantify the changes in carbon stocks and potential carbon emissions due to forest conversion. Limited data exists for ecosystem carbon stocks in tropical peatlands particularly for soil carbon, and even fewer for carbon emissions that would arise from vegetation cover change of peat swamp forest. The lack of data becomes a major problem for stakeholders at national level to develop policy related to reduction of national greenhouse gas emissions from land-use change sector on 
peatlands. This data can be used to enrich global and national forest inventory data to revise second forest reference emissions level document.

A preliminary carbon stock inventory in peat swamp forest over shallow peats ( $<3 \mathrm{~m}$ ) in Tanjung Puting reported stocks to range from 863 to $1048 \mathrm{Mg} \mathrm{C} / \mathrm{ha}$ (Murdiyarso et al. 2009). We expanded our measurements to slightly deeper peat forests and oil palm plantations located in close proximity to the peat swamp forest sites. The objectives of this study were to quantify the carbon stocks of intact peat swamp forests, secondary forests, and oil palm plantations and estimate potential emissions from vegetation carbon change due to forest to oil palm conversion. To accomplish these objectives, we (1) quantified the structure and composition of primary forest, secondary forest, and oil palm plantation and (2) measured the total ecosystem $\mathrm{C}$ stocks in each ecosystem.

\section{Materials and Methods}

\section{Study Site}

Study sites were located in the Tanjung Puting region, which is $\sim 25 \mathrm{~km}$ from the city of Pangkalan Bun in Central Kalimantan Indonesia (Fig. 10.1). The climate of Central Kalimantan is classified as humid-tropic, with annual rainfall of 2000-4000 mm/yr (Ministry of Environment and Forestry 2015). The annual pattern of rainfall in the study area is influenced by a southeast dry monsoon and a northeast wet monsoon. Most precipitation occurs during the wet season between the months of September
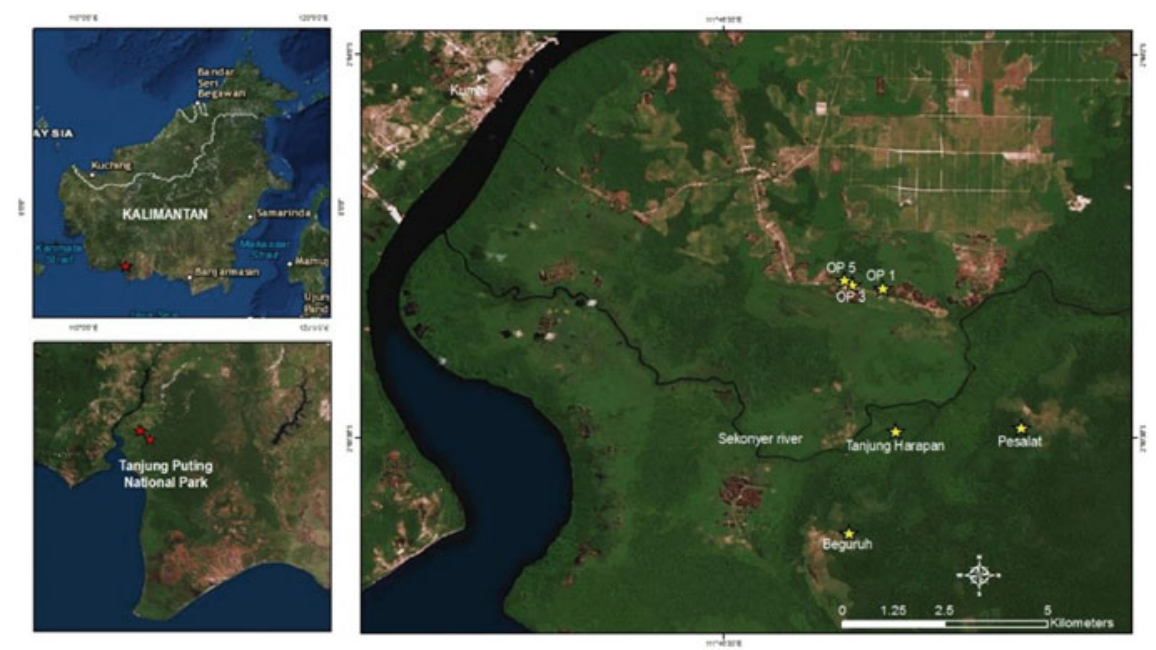

Fig. 10.1 Location of study areas in Tanjung Puting, Indonesia 
Table 10.1 Location and peat depth of sampling locations in Tanjung Puting, Indonesia

\begin{tabular}{l|l|l|l|l}
\hline Ecosystem & Site & Latitude & Longitude & Mean Peat thickness $(\mathrm{cm})$ \\
\hline Primary forest & Beguruh & $\mathrm{S} 2^{\circ} 50^{\prime} 51^{\prime \prime}$ & $\mathrm{E} 111^{\circ} 48^{\prime} 11^{\prime \prime}$ & $290 \pm 23$ \\
\hline Primary forest & Pesalat & $\mathrm{S} 2^{\circ} 49^{\prime} 21^{\prime \prime}$ & $\mathrm{E} 111^{\circ} 50^{\prime} 24^{\prime \prime}$ & $155 \pm 6$ \\
\hline Secondary forest & Tanjung Harapan & $\mathrm{S} 2^{\circ} 49^{\prime} 24^{\prime \prime}$ & $\mathrm{E} 111^{\circ} 48^{\prime} 46^{\prime \prime}$ & $27 \pm 2$ \\
\hline Oil palm & OP1 & $\mathrm{S} 2^{\circ} 47^{\prime} 33^{\prime \prime}$ & $\mathrm{E} 111^{\circ} 48^{\prime} 36^{\prime \prime}$ & $20 \pm 2$ \\
\hline Oil palm & OP3 & $\mathrm{S} 2^{\circ} 47^{\prime} 18^{\prime \prime}$ & $\mathrm{E} 111^{\circ} 48^{\prime} 10^{\prime \prime}$ & $47 \pm 3$ \\
\hline Oil palm & OP5 & $\mathrm{S} 2^{\circ} 47^{\prime} 28^{\prime \prime}$ & $\mathrm{E} 111^{\circ} 48^{\prime} 7^{\prime \prime}$ & $47 \pm 4$ \\
\hline
\end{tabular}

to May and less during a relatively dry season from June to August (Ministry of Environment and Forestry 2015). Based upon the weather stations installed at the research sites, the annual rainfall recorded from the weather stations during our sampling period was below-average annual precipitation $(1870 \mathrm{~mm} / \mathrm{yr})$. Mean air temperature was $31.4^{\circ} \mathrm{C}$. The peat in the area of Tanjung Puting is classified as ombrogenous (Ministry of Environment and Forestry 2015) where precipitation is the major supply of water and nutrients to the ecosystem (Page et al. 2006). The peat in this region was estimated to form beginning about $22,120{ }^{14} \mathrm{C} \mathrm{yr} \mathrm{BP}$ (Weiss et al. 2002), with peat accumulation rate is $0.54 \mathrm{~mm} /$ year (Dommain et al. 2011) .

Two of the forest sites were relatively intact (Beguruh and Pesalat) and one site was a secondary forest (Tanjung Harapan). The secondary forest was located about $1 \mathrm{~km}$ from an abandoned village and was disturbed at least 30 years ago and most likely much earlier than what we expected. The forest sites were located inside the National Park of Tanjung Puting, while the oil palm plantations were located on the opposite side of the Sekonyer River nearby the village of Bedaun. Global Positioning System (GPS) readings were utilized to determine geographic coordinates for each site (Table 10.1). We determined the oil palm plantation age through interviews with farmers/landowners and Bedaun and Sekonyer residents. Oil palm management practices were similar across the sites and were managed by smallholders.

We sampled three oil palm plantations and all had drainage canals constructed around their perimeter. The oil palm plantation sites were (1) One-year old (OP1): This was a small-scale plantation with total area of 1 ha. At OP1, the primary forest clearing occurred in 1989 (about 27 years previously) with slash and burn of the standing forest. The valuable trees were cut and removed, and the remaining biomass was dried for about 1-2 months during dry months then burned. The land was abandoned in one year and was utilized for dry rice cultivation for two years until 1991. The farmer allowed land to lie fallow from 1993 to 2008. In 2008, the land was slashed and burned again for rice cultivation, which was practiced until 2010. The land was fallowed for one year, and in late 2011 the farmer again cleared the fallowed land through slash and burn for oil palm plantation. (2) Three-year-old oil palm plantation or OP3: The forest clearing occurred in 2005 by via slash and burn. The farmer cultivated rice from 2005 to 2007 and allowed land to lie fallow from 2007 to 2009 . The oil palm plantation was established in 2009. (3) Five-year-old oil palm plantation or OP5. The primary forest was slashed and burned in 1989 for cultivation and then 
fallowed. The secondary forest formed on this site was cleared in 2006 via slash and burn. Before the oil palm plantation was established in 2008, the land was utilized for rice and vegetable crops for 2 years.

\section{Field Sampling}

We determined the composition, structure, and ecosystem carbon stocks following methods outlined by Kauffman et al. In the forest sites, six $10 \mathrm{~m}$ fixed-radius (0.0314 ha) plots were established $50 \mathrm{~m}$ apart along a $250 \mathrm{~m}$ transect as depicted in Fig. 10.2. Due to area limitation in the plantations, three $10 \mathrm{~m}$ fixed-radius plots were established $20 \mathrm{~m}$ apart along a $40 \mathrm{~m}$ transect as shown in Fig. 10.3. In addition, palm height and density were measured in a square plot $(50 \mathrm{~m} \times 50 \mathrm{~m})$ established in each plantation site.

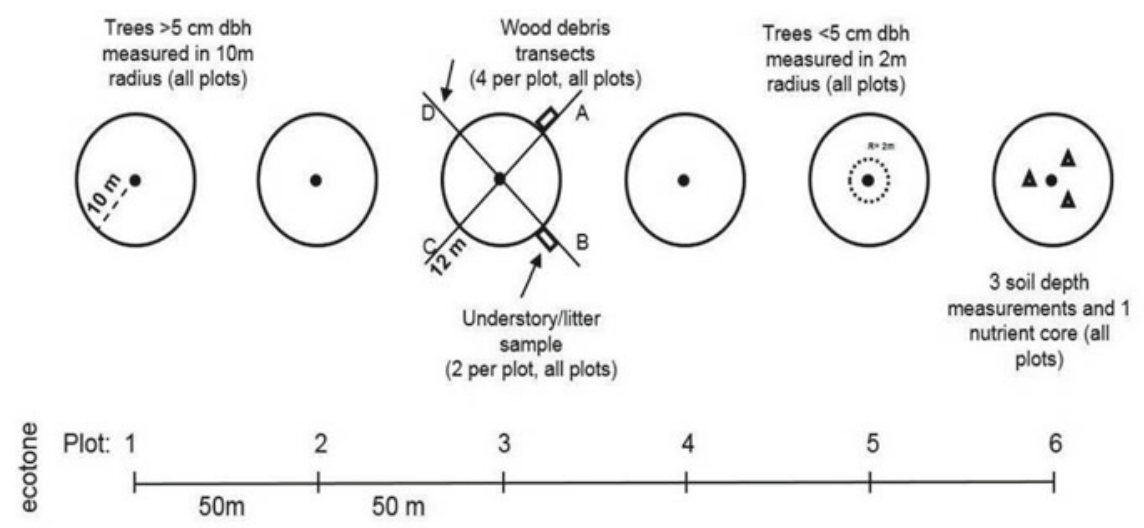

Fig. 10.2 The plot layout for $\mathrm{C}$ stock assessment of peat swamp forests in Tanjung Puting, Indonesia (modified from Kauffman et al. 2011)

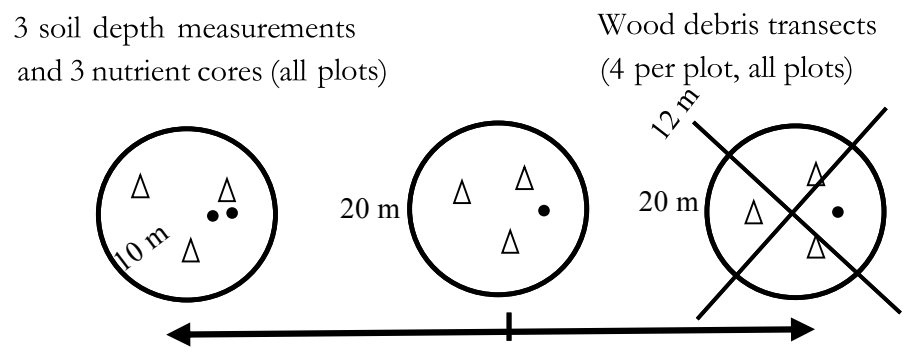

Fig. 10.3 The plot layout for soil C stock assessment of oil palm plantations in Tanjung Puting, Indonesia 


\section{Forest Structure and Composition}

Structure and species composition of trees were determined through tree identification and measurement of the diameter at breast height (dbh; $1.30 \mathrm{~m}$ height or $10 \mathrm{~cm}$ above the area of buttresses or other flared tree bases) of all trees in the circular plots. The tree size class distribution in forest sites was separated into $10 \mathrm{~cm}$ diameter classes. We also recorded tree status (dead or alive). Live trees with dbh $>2 \mathrm{~cm}$ were identified in all circular plots. Samples from plants not identified in the field were determined at the Indonesian Institute of Science or the Lembaga Ilmu Pengetahuan Indonesia (LIPI) in Bogor, Indonesia. Based on the field data, we calculated the mean basal area, tree density, and Importance Values Index (IVI) to describe relative abundance of each tree species. Species diversity indices were also calculated, including Shannon'n (H'), Simpson's reciprocal, and Shannon's evenness (H’E) (Sheehan 1984).

\section{Overstory C Stocks: Trees and Oil Palm Vegetation}

Allometric equations were used to calculate tree and oil palm biomass. The allometric equation by Manuri et al. (2014) was selected to estimate tree biomass in forest sites (Table 10.2). Dead tree biomass was estimated by applying to the allometric equation used for living tree biomass a correction factor based on dead tree status (BSN 2011). The allometric equation based on palm height presented by Khasanah et al. (2015) was chosen to determine oil palm biomass. The palm height was defined as the trunk height from ground level to the lowest frond in palm canopy (Khasanah et al. 2015). Root biomass in all types of ecosystems was estimated based upon a general belowground allometric equation provided by Cairns et al. (1997). This was based

Table 10.2 Equations to estimate aboveground biomass in forest and oil palm plantation sites in Tanjung Puting, Indonesia

\begin{tabular}{l|l|l}
\hline C pool & Equation & Factor C conversion \\
\hline Live tree biomass $(\mathrm{kg} /$ tree $)$ & $\mathrm{AGB}_{\text {tree }}=0.136 * \mathrm{dbh}^{2.513}$ & 0.48 \\
\hline Oil palm biomass $(\mathrm{Mg} / \mathrm{palm})$ & $\mathrm{AGB}_{\mathrm{OP}}=0.0939 * \mathrm{H}+0.0951$ & 0.48 \\
\hline Deadwood biomass $(\mathrm{kg})$ & & 0.48 \\
\hline Status 2 & $\mathrm{AGB}_{\mathrm{dw}}=0.8 *\left(0.136 * \mathrm{dbh}^{2.513}\right)$ & \\
\hline Status 3 & $\mathrm{AGB}_{\mathrm{dw}}=0.7 *\left(0.136 * \mathrm{dbh}^{2.513}\right)$ & \\
\hline Root biomass & $\begin{array}{l}\mathrm{AGB}_{\mathrm{root}}=\exp (-1.085+0.9256 * \mathrm{ln} \\
\left(\mathrm{AGB}_{\mathrm{OP} / \mathrm{tree}}\right)\end{array}$ & 0.39 \\
\hline Woody debris biomass $(\mathrm{Mg})$ & & 0.50 \\
\hline$>7.5 \mathrm{~cm}$ diameter & $\mathrm{AGB}_{\mathrm{wd}}=\mathrm{sg} *\left[\left(\mu^{2} \Sigma \mathrm{D}^{2}\right) /(8 * \mathrm{~L})\right]$ & \\
\hline $2.5-5.5 \mathrm{~cm}$ & $\mathrm{AGB}_{\mathrm{wd}}=\mathrm{sg} *\left[\mu^{2} *\left(\mathrm{NQMD}^{2}\right) /(8 * \mathrm{~L})\right]$ & \\
\hline
\end{tabular}


on an assumption that root: shoot ratio of oil palm plantation is equal to another tree vegetation (Jourdan and Rey 1997). Vegetation C mass was calculated from biomass by multiplying by a factor of 0.48 and 0.39 for vegetation and root biomass, respectively (Kauffman and Donato 2012).

Symbols used in the equations area: $\mathrm{AGB}=$ Aboveground biomass, $\mathrm{dbh}=\mathrm{diam}-$ eter at breast height $(\mathrm{cm}), H=$ height of the palm $(\mathrm{m}), \mathrm{sg}=$ specific gravities $\left(\mathrm{g} / \mathrm{cm}^{3}\right)$ to convert volume to downed wood biomass are from Chao et al. (2008). Sg for solid and rotten woody debris are 0.5 and 0.23 , respectively. $N=$ number of pieces of woody debris pieces, QMD = quadratic mean diameter of size class $(\mathrm{cm})$, and $L=$ the transect length $(\mathrm{m})$.

\section{Litter and Understory}

Litter and understory biomass were determined through destructive sampling. In each circular plot, we harvested litter and understory vegetation from two $56 \mathrm{~cm} \times$ $56 \mathrm{~cm}$ microplots. Litter consisted of leaves, flowers, fruits, bark fragments, seeds, and small twigs/woody stems. All plant samples were placed in a bag and transported to the laboratory where they were oven-dried to a constant mass at $60{ }^{\circ} \mathrm{C}$ and then weighed. The organic carbon content of the litter and understory were determined by the induction furnace method with a Carbon Nitrogen Analyzer (LECO Corporation, St. Joseph, Michigan, USA) in the Soil Biotechnology laboratory, Bogor Agricultural University, Indonesia. The litter C content in the oil palm plantation was estimated based on Khasanah et al. (2015) study.

\section{Downed Wood}

The mass of downed wood was measured using the planar intersect technique (Kauffman et al. 2016; Kauffman and Donato 2012). At the center of each circular plot, four $12 \mathrm{~m}$ transects were established diagonally at $45^{\circ}$ off the main transect (Figs. 2 and 3). Along each transect, coarse downed wood (diameter $>7.5 \mathrm{~cm}$ ) was measured from 2 to $12 \mathrm{~m}$ and fine downed wood (diameter $2.5-7.5 \mathrm{~cm}$ ) was measured from 2 to $7 \mathrm{~m}$. Coarse downed wood was separated into sound and rotten classes. Fine downed wood was only counted. A quadratic mean diameter (QMD) was used to estimate volume of the fine downed wood (Kauffman et al. 2016). We used data of the specific gravity of downed wood reported by Chao et al. (2008). Volume and specific gravity of downed wood were multiplied to estimate biomass. The biomass was multiplied by a factor of 0.50 to estimate downed wood C mass (Kauffman and Donato 2012). 


\section{Soil Carbon}

Peat depth and sample cores were extracted from three sampling points near the center of each circular plot. We measured peat depth by forcing a steel open-faced peat auger downward through peat horizon to the organic-mineral transitional horizon. An extension handle was used if peat depth was greater than $1 \mathrm{~m}$. Measurements of soil bulk density and $\mathrm{C}$ concentration at various peat depths were taken to determine the soil C stocks (Donato et al. 2011; Kauffman et al. 2011). The core was systematically divided into the depth intervals of $0-15,15-30,30-50,50-100$, and $>100 \mathrm{~cm}$ (if mineral layers were not detected before $100 \mathrm{~cm}$ depth). Samples of a known volume were carefully placed in whirlpak bags and transported to the Bogor Agricultural University for laboratory analysis. Soil samples were dried to a constant mass at $60{ }^{\circ} \mathrm{C}$ and weighed to obtain soil bulk density. The organic carbon content of soil samples was determined via the induction furnace method using a carbon-nitrogen analyzer (LECO Corporation, St. Joseph, Michigan, USA). The induction furnace with an elemental carbon analyzer is considered the most reliable method compared to other $\mathrm{C}$ determination methods, e.g., wet combustion and loss of ignition (Kauffman and Donato 2012) in tropical peat soils (Farmer et al. 2014). The soil carbon stocks were calculated as the products of bulk density and carbon concentration combined with plot-specific peat depth.

\section{Statistical Analyses}

Microsoft Excel and IBM SPSS were used for data analysis with a probability threshold ( $p$ value) of 5\%. The residual values of soil properties (bulk density, C, N, and $\mathrm{C} / \mathrm{N}$ ratio), ecosystem $\mathrm{C}$ stocks, and their log transformations were not normally distributed based on the Shapiro-Wilk test. Differences in soil properties, biomass, and $\mathrm{C}$ among ecosystems (primary forest, secondary forest, and oil palm plantation) were tested using the non-parametric Kruskal-Wallis test. If the result was significant, a pairwise comparison test was applied to determine which means were significantly different.

\section{Results}

\section{Ecosystem Structure and Composition}

The distribution of tree diameters described a typical reverse J-shaped curve in all forest sites where small trees were most abundant (Fig. 10.4). Within forest sites, there was considerable site-to-site variation in the distribution of tree diameter classes and therefore forest structure. In general, the range in diameters was larger in Beguruh and 

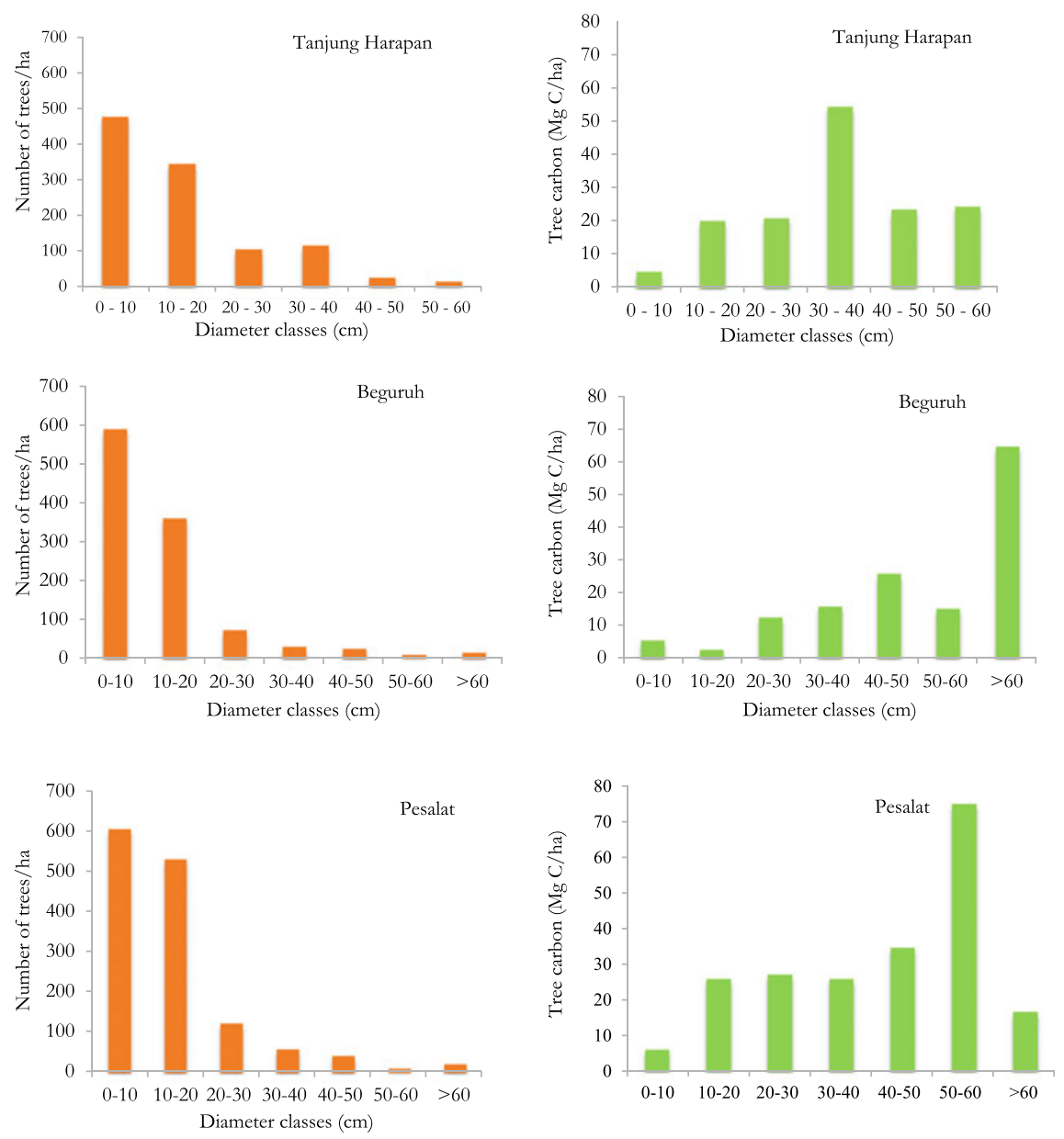

Fig. 10.4 Distribution of tree density and aboveground $\mathrm{C}$ stock by $10 \mathrm{~cm}$ diameter classes in Tanjung Harapan, Beguruh, and Pesalat forest sites in Tanjung Puting, Indonesia

Pesalat sites (primary forest) compared to Tanjung Harapan site (secondary forest). Living trees with $\mathrm{dbh}>60 \mathrm{~cm}$ were present in primary forests (Pesalat and Beguruh) while in the secondary forest, Tanjung Harapan, they were not present. The small trees $(\mathrm{dbh}<20 \mathrm{~cm})$ were also lower in abundance at Tanjung Harapan than Beguruh and Pesalat sites (Fig. 10.4). The small trees comprised 76, 86, and $82 \%$ of the total distribution of trees in Tanjung Harapan, Beguruh, and Pesalat, respectively. Overall, Tanjung Harapan site differed from Pesalat and Beguruh sites, particularly in having a lower density of small $(\mathrm{dbh}<20 \mathrm{~cm})$ and large trees $(\mathrm{dbh}>60 \mathrm{~cm})$.

We also found difference between secondary and primary forests in tree carbon stock distribution among diameter classes (Fig. 10.4). Tree C stock in secondary forest was mostly dominated by tree with $\mathrm{dbh}<40 \mathrm{~cm}$, which comprised $68 \%$ of the 
total vegetation $\mathrm{C}$ stocks. In contrast, tree with $\mathrm{dbh}>40 \mathrm{~cm}$ dominated $\mathrm{C}$ vegetation in primary forest sites, comprising 74 and $60 \%$ of the total vegetation $\mathrm{C}$ stocks in Beguruh and Pesalat, respectively.

Shannon's index (H') of forest structure was lower at the secondary forest site (1.13) compared to primary forest sites (1.35 and 1.36 for Beguruh and Pesalat, respectively), thus reflecting a more even-aged stand in the secondary forest. This index poorly described structural diversity among forest sites. Simpson's reciprocal index of the secondary forest Tanjung Harapan was lower (8.44) than Beguruh (14.98) and Pesalat (14.62) sites. Simpson's reciprocal index better illustrated the diversity of the forest structure in Tanjung Harapan, and was different from the Beguruh and Pesalat sites. Furthermore, Pesalat and Beguruh sites had similar Shannon's evenness indices (0.37), which were slightly higher than Tanjung Harapan site (0.34). Lower values of species diversity and evenness indices in Tanjung Harapan reflect signs of early seral forest succession.

The mean basal area of the forest sites was $31.3,28.4$, and $39.6 \mathrm{~m}^{2} /$ ha in Tanjung Harapan, Beguruh, and Pesalat, respectively. The Tanjung Harapan site was dominated by Macaranga motleyana, a pioneer species (Davies and Ashton 1999) with the highest basal area $\left(15 \mathrm{~m}^{2} / \mathrm{ha}\right)$ and importance value index (82\%; Fig. 10.5). The high dominance by a single species in Tanjung Harapan site was consistent with the low values described by Simpson's reciprocal index. Unlike Tanjung Harapan site, no single species dominated in the primary forests (Fig. 10.5). It is interesting to see the presence of Artocarpus heterophyllus (jackfruit), a crop cultivated species, had the 5th highest IVI value (12.4), showing that Tanjung Harapan was formerly utilized for agriculture. Inevitably, the Tanjung Harapan site clearly showed a different structure and composition compared to Beguruh and Pesalat sites. The different composition and structure at Tanjung Harapan reflects past intensive land use prior to its inclusion in Tanjung Puting national park territory.

\section{Aboveground C Stocks}

Ecosystem $\mathrm{C}$ stocks are presented in Table 10.3. In primary forests, the aboveground $\mathrm{C}$ stock was higher in Pesalat $(206 \pm 32 \mathrm{Mg} \mathrm{C} / \mathrm{ha})$ than in Beguruh $(130 \pm 30 \mathrm{Mg}$ $\mathrm{C} / \mathrm{ha} ; p<0.001)$. The mean of vegetation $\mathrm{C}$ stock in primary forest $(168 \pm 31 \mathrm{Mg}$ $\mathrm{C} / \mathrm{ha}$ ) was not significantly different from the stock in secondary forest $(140 \pm 16 \mathrm{Mg}$ $\mathrm{C} / \mathrm{ha} ; p=0.291$ ). The tree carbon pools closely followed basal area across forest plots. In the oil palm plantations, vegetation $\mathrm{C}$ stocks ranged from 7 to $19 \mathrm{Mg} \mathrm{C} / \mathrm{ha}$. There were significant differences among sites in the oil palm plantation $(p<0.001)$, where the highest palm $C$ stock was found at the oldest plantation. Mean aboveground $\mathrm{C}$ stocks in the primary forests were 14 times higher than in the oil palm plantations sites $(p<0.001)$.

The downed wood was a significant $\mathrm{C}$ pool, contributing 12 and $16 \%$ to the total aboveground $\mathrm{C}$ stocks in the primary forests and secondary forest, respectively. This was especially true for oil palm plantations, where the downed wood $\mathrm{C}$ pool 

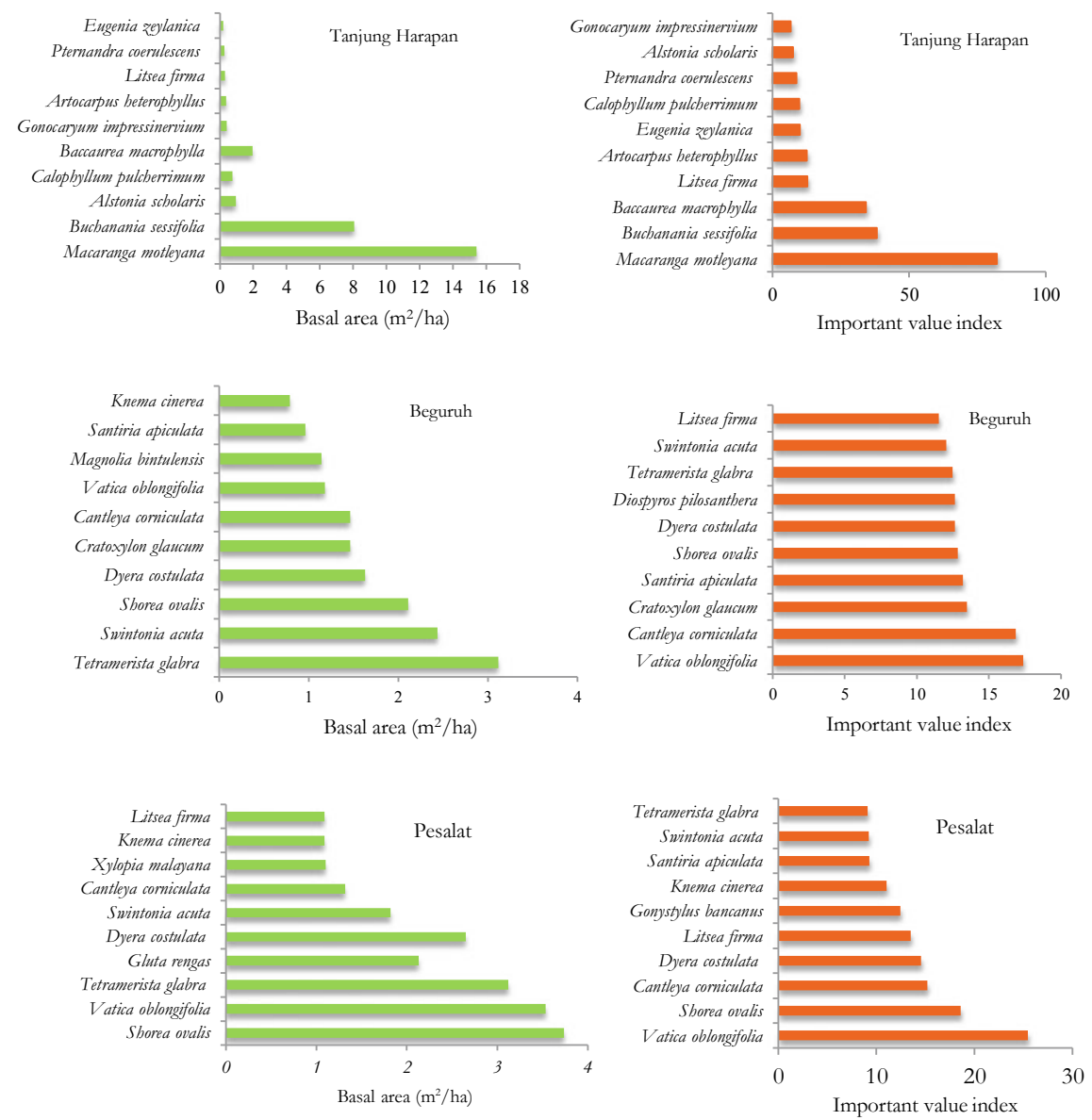

Fig. 10.5 Basal area $\left(\mathrm{m}^{2} / \mathrm{ha}\right)$ and important value index in Tanjung Harapan, Beguruh, and Pesalat forest sites in Tanjung Puting, Indonesia

consisting of residual wood from the forests contributed more than half (55\%) to the total aboveground carbon. The dead trees were an insignificant $\mathrm{C}$ pool, accounting for only 3 and $1 \%$ of the total aboveground biomass in the primary forests and secondary forests, respectively. There were no standing dead trees in the oil palm plantation sites. The dead frond piles $\mathrm{C}$ stocks were found in the oil palm plantations but this $\mathrm{C}$ pool is assumed to be insignificant or may be underestimated.

In forests, mean carbon concentrations of litter and understory were $48.43 \pm$ $0.46 \%$ and $45.02 \pm 0.68 \%$, respectively. Litter and understory $\mathrm{C}$ stocks were $4 \mathrm{Mg}$ $\mathrm{C} /$ ha in forest sites and contributed $2 \%$ to the total aboveground $\mathrm{C}$ stocks. There was less understory and litter in the oil palm plantations because herbicides were regularly applied. 


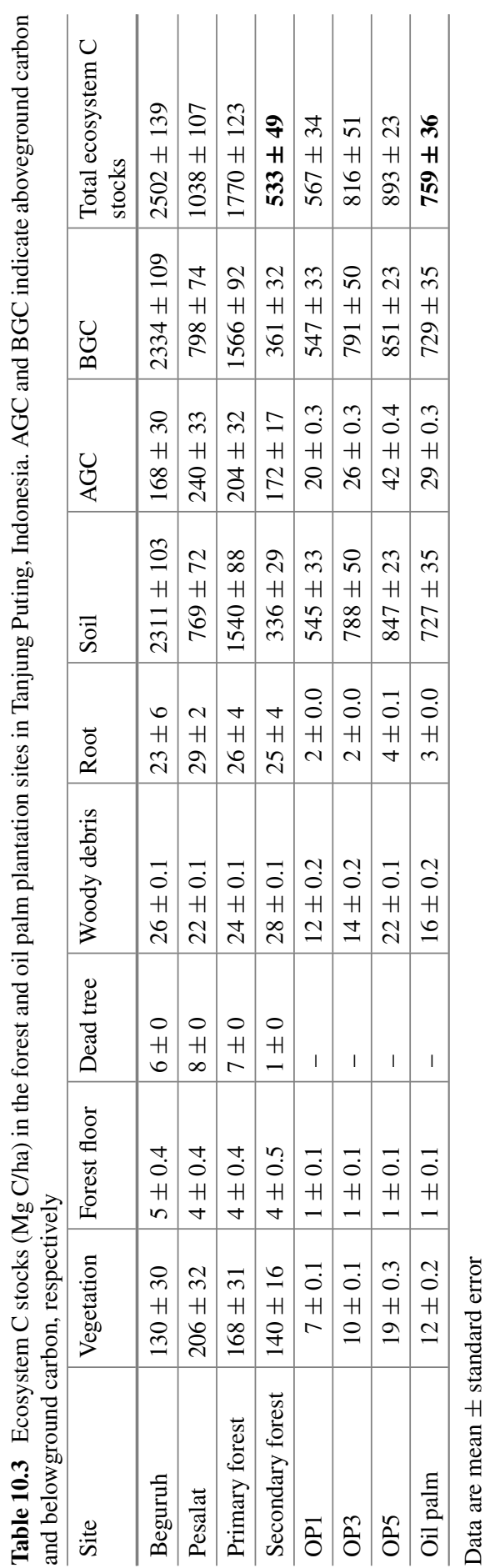


Aboveground $\mathrm{C}$ stock was the highest in the primary forests, followed by secondary forest and oil palm plantations. The mean aboveground $\mathrm{C}$ stock was seven times higher in the primary forests than in oil palm plantation sites $(p<0.001)$ (Table 10.3).

\section{Soil}

The peat was deeper in the primary forests compared to the oil palm plantations or secondary forest (Table 10.4). The mean peat depth of primary forest sites was 223 $\pm 10 \mathrm{~cm}$. In contrast, the mean peat depth of three oil palm plantation sites was significantly lower compared to primary forests, with a mean of $38 \pm 3 \mathrm{~cm}$ ( $p<$ $0.001)$. The lowest peat depth across sites was observed in secondary forest Tanjung Harapan $(27 \mathrm{~cm})$.

There was a significant difference in soil bulk density between primary forest and oil palm plantation sites $(p<0.001$, Table 10.4), which was apparent throughout all depths. The mean bulk density across depths was twice higher in oil palm plantations sites $\left(0.37 \pm 0.05 \mathrm{~g} \mathrm{~cm}^{-3}\right)$ than in primary forest sites $\left(0.17 \pm 0.02 \mathrm{~g} \mathrm{~cm}^{-3} ; p<0.001\right)$. Bulk density of secondary forests $\left(0.30 \pm 0.02 \mathrm{~g} \mathrm{~cm}^{-3}\right)$ was also twice the value in primary forests. Interestingly, we did not observe a significant difference in bulk density between secondary forest and oil palm plantation sites $(p=0.222)$, suggesting a clear effect of past forest clearing and agricultural cultivation in the secondary forest site. Moreover, the higher bulk density and the shallow peat depth in the secondary forest suggest a slow recovery on the peat layers following abandonment.

In general, bulk density tended to decrease with depth in primary forest and oil palm plantation ecosystems, but not in the secondary forest. In oil palm plantations sites, the bulk density at $0-15 \mathrm{~cm}$ peat depth was $0.41 \mathrm{~g} \mathrm{~cm}^{-3}$ or 1.5 times higher than the $0.27 \mathrm{~g} \mathrm{~cm}^{-3}$ average for peat layer $>30 \mathrm{~cm}$. Furthermore, in the primary forest sites, bulk density at $0-15 \mathrm{~cm}$ was $0.25 \mathrm{~g} \mathrm{~cm}^{-3}$ or two times higher compared to $0.13 \mathrm{~g} \mathrm{~cm}^{-3}$ at peat layer $50-100 \mathrm{~cm}$.

The mean $\mathrm{C}$ concentration across depths was similar in the primary forest $(49.42 \pm$ $0.83 \%)$ and oil palm plantation sites $(48.73 \pm 5.05 \%)(p=1.0)$. In both ecosystems, soil $\mathrm{C}$ concentration exceeded $43 \% \mathrm{C}$ at all depths. Peat in the secondary forest had a significantly lower $\mathrm{C}$ concentration but still relatively high at $32 \%(p<0.001)$. In general, soil $\mathrm{C}$ concentration was not affected by depth in all sites (Table 10.4).

Primary forest conversion to oil palm plantations affected soil $\mathrm{N}$ concentration at all soil depths (Table 10.4). There was no significant difference in $N$ concentration between primary and secondary forests $(p=0.299)$. The mean $\mathrm{N}$ concentration in the primary forest, was higher $(1.23 \pm 0.07 \%)$ than at oil palm plantation sites $(0.95 \pm 0.13 \%)(p<0.001)$. The difference in $\mathrm{N}$ concentration between forest and oil palm plantation sites was apparent at all depths. Generally, we observed that soil $\mathrm{N}$ concentration decreased with depth in all sites. In the primary forest sites, $\mathrm{N}$ concentration at the $0-5 \mathrm{~cm}$ peat depth $(1.61 \%)$ was about 1.5 times higher than in the $>100 \mathrm{~cm}$ peat layer $(1.10 \%)$. A similar trend was found in the oil palm plantations 


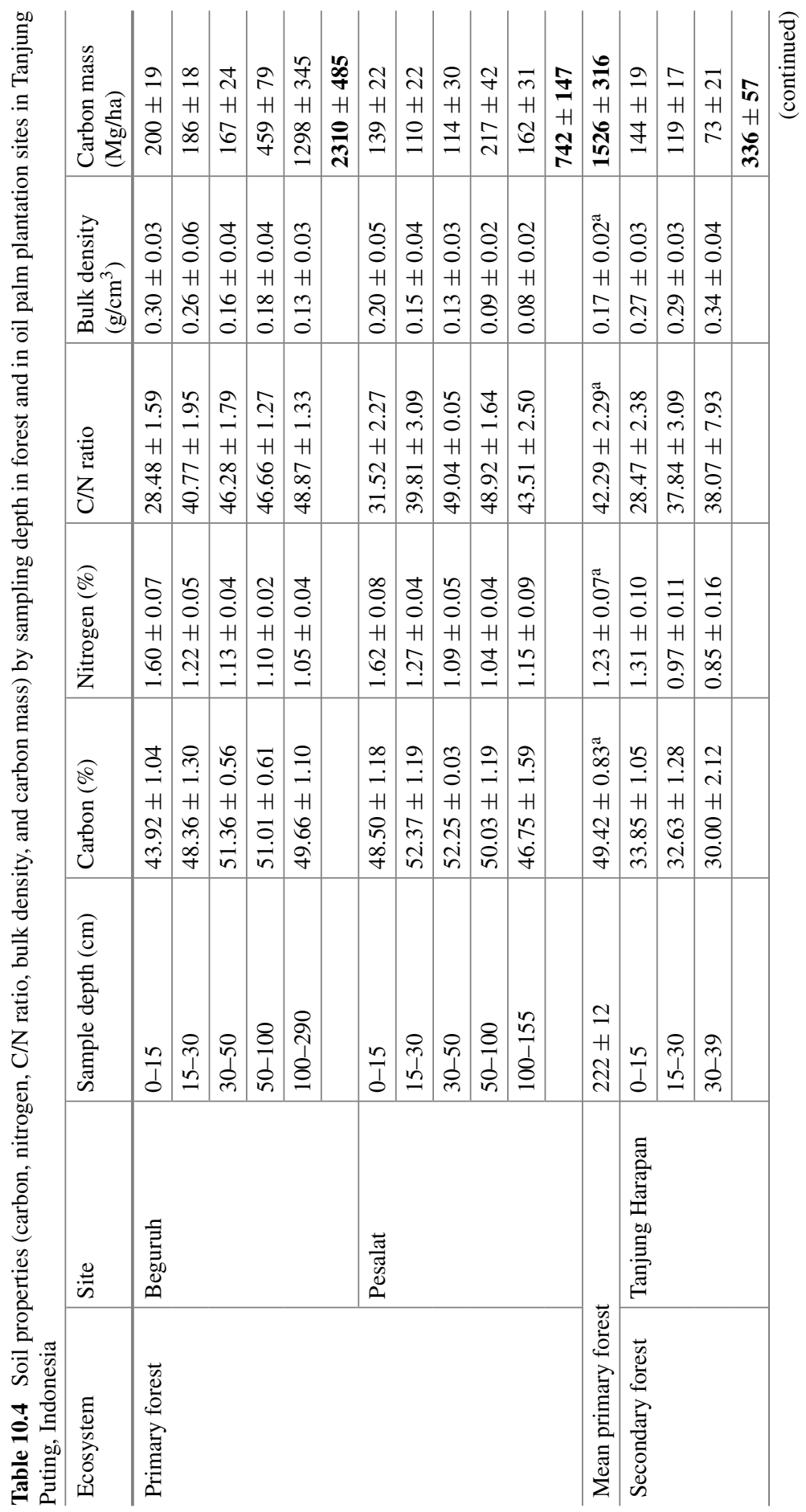




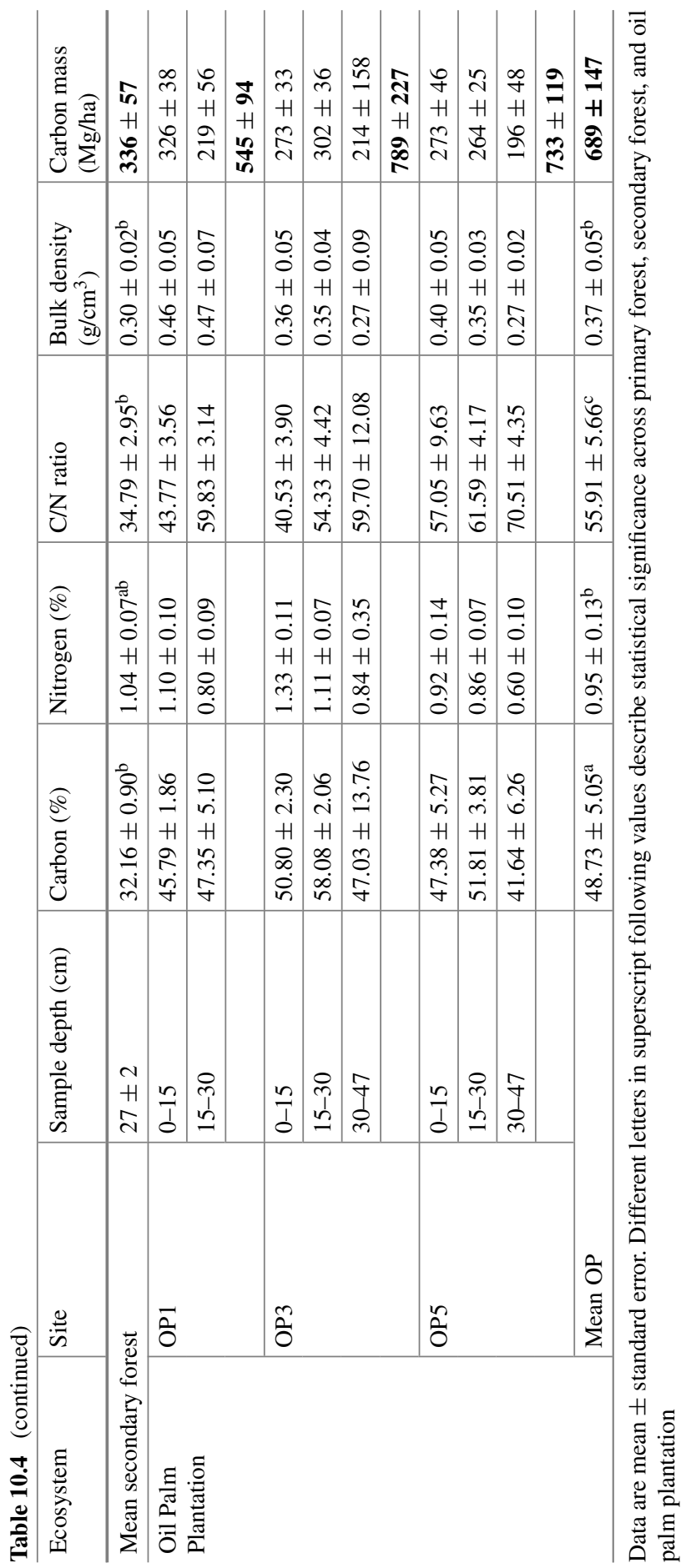




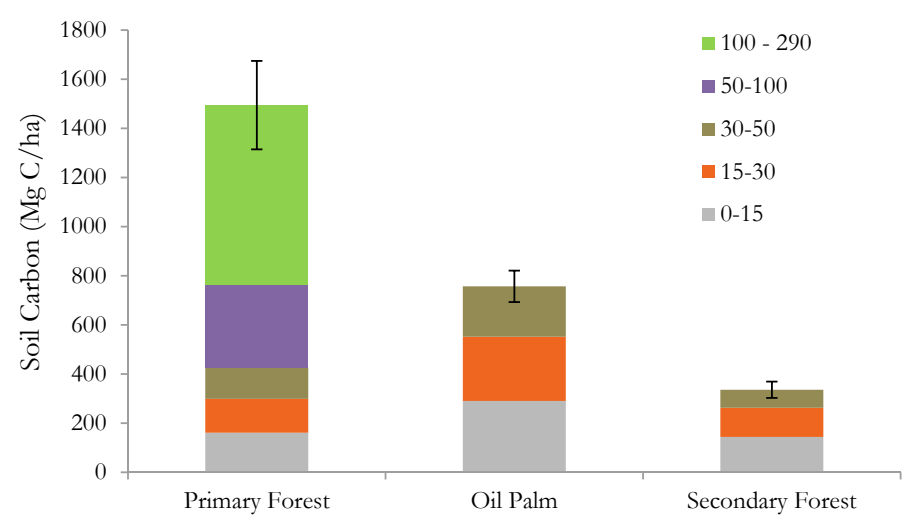

Fig. 10.6 Soil C stocks ( $\mathrm{Mg} \mathrm{C} / \mathrm{ha}$ ) in different peat layers $(\mathrm{cm})$ in primary forest, secondary forest, and oil palm plantation sites in Tanjung Puting, Indonesia. Vertical bars are standard errors

where soil $\mathrm{N}$ content in the $0-15 \mathrm{~cm}$ peat depth $(1.12 \%)$ was about 1.6 times higher than in the peat layer $>30 \mathrm{~cm}(0.72 \%)$.

The relatively deep peat and high $\mathrm{C}$ concentration throughout the profile in the primary forest sites resulted in high soil carbon stocks. The shallow peat depth coupled with lower $\mathrm{C}$ concentration resulted in lower $\mathrm{C}$ soil carbon stock in the secondary forest that in primary forests. The mean soil $\mathrm{C}$ stock was higher in the primary forest sites than in the oil palm plantation sites $(p<0.001$; Fig. 10.6). The mean soil C stock of oil palm plantations was about $47 \%$ of the mean of primary forests. However, carbon density (carbon mass per unit of soil) remained high due to high bulk density in the oil palm plantation sites.

\section{Ecosystem C Stocks}

The mean total ecosystem C stock of the primary forests was $1770 \pm 123 \mathrm{Mg} \mathrm{C} / \mathrm{ha}$. Total ecosystem $\mathrm{C}$ stock was $1038 \mathrm{Mg} \mathrm{C} / \mathrm{ha}$ at Pesalat site and $2502 \mathrm{Mg} \mathrm{C} / \mathrm{ha}$ in Beguruh site (Fig. 10.7). In contrast, the mean total ecosystem $\mathrm{C}$ stock in the oil palm plantations was $759 \pm 36 \mathrm{Mg} \mathrm{C} / \mathrm{ha}$, less than half of the mean of the primary forests $(p<0.001)$. Total ecosystem $\mathrm{C}$ stock for oil palm plantations showed relatively low variation from a minimum of $567 \mathrm{Mg} \mathrm{C} / \mathrm{ha}$ at OP1 to a maximum of $893 \mathrm{Mg}$ C/ha at OP5 (Fig. 10.7). The lowest ecosystem $\mathrm{C}$ stock was found at the secondary forest.

Soil was a primary carbon pool in all land uses. Soil C pools contribute $3 \%$ of the total ecosystem $\mathrm{C}$ stock in the primary forests, ranging from $74 \%$ at Pesalat site to $92 \%$ at Beguruh site. In the oil palm plantations, soil comprised $>95 \%$ of the total ecosystem $\mathrm{C}$ stock in all sites. Lower contribution of soil $\mathrm{C}$ pool to the total ecosystem C stock (63\%) was observed at Tanjung Harapan. Consequently, the ratio 


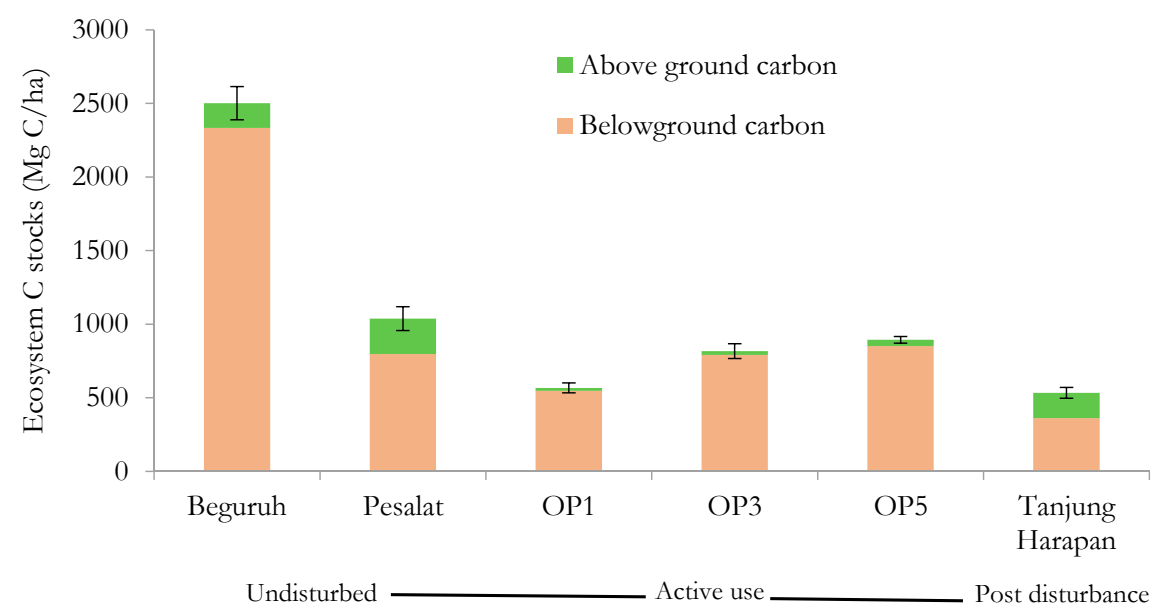

Fig. 10.7 Total ecosystem C stocks ( $\mathrm{Mg} \mathrm{C} / \mathrm{ha}$ ) of peat swamp forests (primary and secondary) and oil palm plantation sites in Tanjung Puting, Indonesia. Vertical bars are standard errors

of the aboveground to belowground $\mathrm{C}$ stock was highest in secondary forest site with an estimated value of 0.48 , followed by primary forest $(0.19)$ and oil palm plantation (0.04). Peat swamp forest conversion resulted in substantial $\mathrm{C}$ losses from vegetation cover change, of $640 \mathrm{Mg} \mathrm{CO}_{2} /$ ha.

\section{Discussion}

\section{Composition and Structure of Forest}

Tanjung Harapan as secondary forest clearly shows differences on diameter distribution, basal area, and important value index compared to two other primary forest sites; Beguruh and Pesalat. It clearly indicates that Tanjung Harapan is at early to medium stage growth of secondary forest and recovering from human disturbances in particular encroachment in the past. The secondary forest carbon pool at Tanjung Harapan site suggests a rapid rate of carbon sequestration when sites are abandoned and native vegetation is allowed to grow (in the absence of fire and other human disturbances). 


\section{Ecosystem C Stocks}

Limited studies on aboveground $\mathrm{C}$ stocks have been conducted in tropical peat swamp forests (Table 10.5) and even fewer exist for oil palm plantations and secondary forests (but see Murdiyarso et al. 2009; Warren et al. 2012). The estimate of total aboveground C stocks of primary forest sites in this present study (204 Mg C/ha) was slightly higher than the forest sampled in the same area by Murdiyarso et al. (2009) who reported mean aboveground $\mathrm{C}$ stocks of $143 \mathrm{Mg} \mathrm{C} / \mathrm{ha}$. Our results fall within

Table 10.5 Summary of ecosystem C stocks (expressed in $\mathrm{Mg} \mathrm{C/ha)} \mathrm{of} \mathrm{peat} \mathrm{swamp} \mathrm{forests} \mathrm{in}$ Indonesia (except Micronesia and Mexico)

\begin{tabular}{|c|c|c|c|c|c|}
\hline Location & $\begin{array}{l}\text { Peat depth } \\
(\mathrm{cm})\end{array}$ & $\begin{array}{l}\mathrm{AGC}(\mathrm{Mg} \\
\mathrm{C} / \mathrm{ha})\end{array}$ & $\begin{array}{l}\text { BGC (Mg } \\
\text { C/ha) }\end{array}$ & $\begin{array}{l}\text { Ecosystem C } \\
(\mathrm{Mg} \mathrm{C} / \mathrm{ha})\end{array}$ & Sources \\
\hline Mexico & 150 & $95 \pm 16$ & - & $722 \pm 64$ & $\begin{array}{l}\text { Adame et al. } \\
\text { (2015) }\end{array}$ \\
\hline $\begin{array}{l}\text { Kosrae, } \\
\text { Micronesia }\end{array}$ & - & & $165-388$ & & $\begin{array}{l}\text { Chimner and } \\
\text { Ewel (2005) }\end{array}$ \\
\hline Various sites & 450 & - & $2774 \pm 595$ & - & $\begin{array}{l}\text { Jaenicke et al. } \\
\text { (2008) }\end{array}$ \\
\hline South Sumatra & & 144 & & & Novita (2010) \\
\hline Jambi & - & 141 & - & & $\begin{array}{l}\text { Krisnawati } \\
\text { et al. (2012) }\end{array}$ \\
\hline Jambi & - & 153 & - & - & $\begin{array}{l}\text { Krisnawati } \\
\text { et al. (2012) }\end{array}$ \\
\hline Riau & - & 131 & & & Istomo (2002) \\
\hline Riau $^{\mathrm{a}}$ & - & 56 & & & $\begin{array}{l}\text { Istomo and } \\
\text { Wibisono } \\
\text { (2009) }\end{array}$ \\
\hline $\begin{array}{l}\text { Central } \\
\text { Kalimantan }\end{array}$ & - & $157 \pm 21$ & & & $\begin{array}{l}\text { Krisnawati } \\
\text { et al. (2014) }\end{array}$ \\
\hline $\begin{array}{l}\text { Central } \\
\text { Kalimantan }^{\mathrm{a}}\end{array}$ & - & $140 \pm 2$ & & & $\begin{array}{l}\text { Krisnawati } \\
\text { et al. (2014) }\end{array}$ \\
\hline $\begin{array}{l}\text { Central } \\
\text { Kalimantan }\end{array}$ & - & 118 & & & $\begin{array}{l}\text { Simbolon } \\
(2015)\end{array}$ \\
\hline $\begin{array}{l}\text { Central } \\
\text { Kalimantan }\end{array}$ & - & 214 & & & $\begin{array}{l}\text { Simbolon } \\
(2015)\end{array}$ \\
\hline $\begin{array}{l}\text { West } \\
\text { Kalimantan }\end{array}$ & $650-1050$ & 122 & 3899 & 4021 & Basuki (2017) \\
\hline Tanjung Puting & 46 & & & $894 \pm 112$ & $\begin{array}{l}\text { Murdiyarso } \\
\text { et al. (2009) }\end{array}$ \\
\hline $\begin{array}{l}\text { Tanjung } \\
\text { Puting }^{\mathrm{a}}\end{array}$ & 27 & $172 \pm 17$ & $361 \pm 32$ & $533 \pm 49$ & This study \\
\hline Tanjung Puting & 223 & $204 \pm 32$ & $1566 \pm 92$ & $1770 \pm 123$ & This study \\
\hline
\end{tabular}

${ }^{\mathrm{a}}$ secondary forest/degraded forest 
range of aboveground $\mathrm{C}$ stocks in other Indonesian primary peat swamp forests of 118-214 Mg C/ha (Table 10.5). Contrastingly, a peat swamp forest in Mexico had lower aboveground $\mathrm{C}$ stocks (Adame et al. 2015). Although the peat swamp forest in Mexico had two times higher tree density (2469 trees/ha) compared to this study, the area was dominated by only a single species of Pachira aquatic (Adame et al. 2015).

Our analysis showed that aboveground carbon contributed about $10 \%$ to the total ecosystem $\mathrm{C}$ stocks in the primary forests (Table 10.3) which is comparable to results from previous studies in the tropics which reported that $10-13 \%$ of the total ecosystem C stocks were allocated above ground (Draper et al. 2014; Murdiyarso et al. 2009; Adame et al. 2015; Bhomia et al.2019). In areas where the peat is deep, a smaller contribution of aboveground carbon to total ecosystem $\mathrm{C}$ stocks can be expected. For example, Basuki (2017) reported that aboveground carbon only contributed less than $4 \%$ to total ecosystem $\mathrm{C}$ stocks in West Kalimantan, Indonesia where the peat thickness was more than $9 \mathrm{~m}$ and contained 3,800 $\mathrm{Mg} \mathrm{C} / \mathrm{ha}$.

Globally, carbon stocks of recently established oil palm plantations 1-5-year old fall between 1.3 and 16.2 Mg C/ha. The oil palm $\mathrm{C}$ vegetation stocks in this study were comparable to that reported by Corley et al. (1971) for OP1, and $\mathrm{Ng}$ et al. (1986) for OP3 and OP5. Our study reported aboveground carbon stocks from young plantation, hence the estimates are lower than the average carbon stocks in oil palm plantation over a full rotation cycle. The variation of oil palm $\mathrm{C}$ stocks among studies may be related to differences in soil condition, management practices (e.g., palm density and fertilizer application) (Syahrinuddin 2005; Henson 2003), or sampling approaches (destructive or allometric). A review analysis from data of aboveground carbon of oil palm plantations in Malaysia and Indonesia showed that oil palm $\mathrm{C}$ stocks were strongly correlated with the age of the stands, which was best explained by a power model (Oil palm C stocks $=3.4713 *$ age $e^{0.8382} ; r^{2}=0.82$ ). The ecosystem C stocks in the final stage of oil palm plantations ( $798 \mathrm{Mg} \mathrm{C} / \mathrm{ha}$ ) were $45 \%$ of total ecosystem in primary forests, suggesting that increasing of aboveground $\mathrm{C}$ stocks over time is insignificant in oil palm plantations and will never compensate the expense of AGB loss before forest conversion. the time-averaged aboveground $\mathrm{C}$ managed by smallholder oil palm plantation is $37.76 \mathrm{Mg} \mathrm{C} /$ ha for one cycle in Indonesia where almost half of above ground carbon stocks from oil palm plantation in Peruvian Amazonia reported by Malaga et al (2020) (78.2 $\pm 2.0 \mathrm{Mg} \mathrm{C} / \mathrm{ha}$ ).

Conversion of peat swamp forest to oil palm plantations resulted in substantial carbon losses to the atmosphere from changes in vegetation $\mathrm{C}$ stock. As hypothesized, we found that the conversion of forest to oil palm plantations significantly reduced the vegetation carbon by approximately $93 \%$ (Table 10.3 and Fig. 10.8). This was similar to the conclusion of Basuki (2017) who also found more than $99 \%$ of plant carbon reduction after conversion of primary forest on deep peats to oil palm plantation in West Kalimantan, Indonesia. Our estimate was higher than the one by Kho and Jepsen (2015), who reported about $81-88 \%$ of the plant C stocks were lost due to forest conversion to oil palm plantations in Malaysia.

In a chronosequence scenario, the secondary forest in Tanjung Harapan had the rapidly accumulate aboveground $\mathrm{C}$ stocks but not peat. It is important to point out 


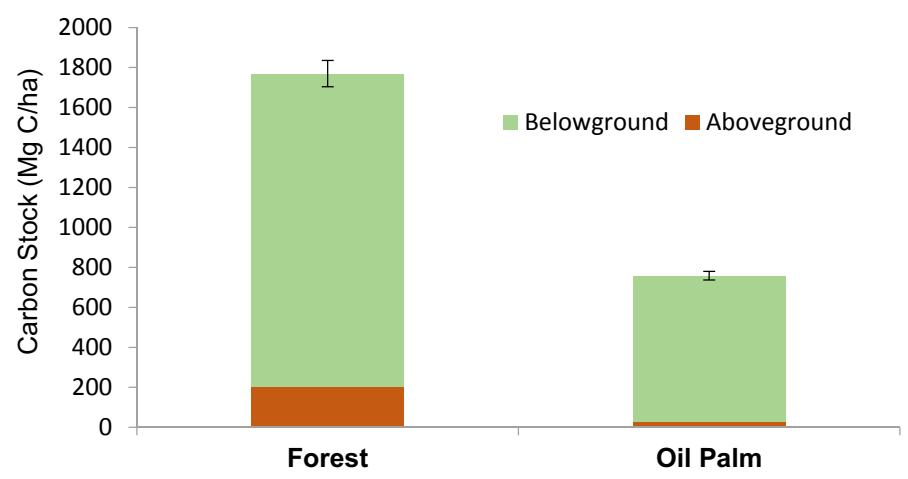

Fig. 10.8 Ecosystem $\mathrm{C}$ stocks ( $\mathrm{Mg} \mathrm{C} / \mathrm{ha}$ ) in the primary peat swamp forest and oil palm plantation sites in Tanjung Puting, Indonesia

that the slow carbon accumulation on peat in secondary forests reveals that peat is a non-renewable source in that it takes centuries to accumulate and is lost quickly during land-use conversion (slow in, fast out). Tanjung Harapan, as secondary forest site, may reach an aboveground carbon stock equal to that in primary forest sites, but not in belowground carbon. Finally, the probabilities of permanent $\mathrm{C}$ loss following forest disturbance are not necessarily equal to carbon gain during regrowth period. This suggests that restoration of peat swamp forest is important but conservation is the most effective way to conserve more carbon on peat in the tropics.

Aboveground C stocks of the Tanjung Harapan site were $172 \mathrm{Mg} \mathrm{C} / \mathrm{ha}$, which was $84 \%$ to the total aboveground $\mathrm{C}$ stock of primary forests in the Pesalat and Beguruh sites after at least 30 years disturbance. This sequestration rate of about $5.7 \mathrm{Mg}$ $\mathrm{C}$ ha/yr is comparable to results from other secondary forests such as results by Hughes et al. (1999, 2000) who found rates to be about $2.5 \mathrm{Mg} \mathrm{C}$ ha/yr in secondary in the heavily deforested sites in Mexico. These results imply that reforested peat swamp forests may provide a new opportunity for climate change mitigation in tropical peatlands. However, there are some critical gaps in our knowledge, and further scientific studies are needed to investigate the role of secondary peat swamp forests in carbon re-accumulation aboveground after long-term disturbance.

Root $\mathrm{C}$ stocks in primary and secondary forest sites were estimated to range from 23 to $29 \mathrm{Mg} \mathrm{C} / \mathrm{ha}$. These findings are comparable to root carbon stocks from primary peat swamp forests in Riau, Indonesia (33 Mg C/ha) (Istomo 2002). Our results were consistent with root $\mathrm{C}$ stocks reported by Krisnawati et al. (2014); 24 and $21 \mathrm{Mg}$ $\mathrm{C} /$ ha for primary and secondary peat swamp forests in Central Kalimantan, Indonesia, respectively. Further, root: shoot ratios from peat swamp forests in the present study were $18 \%$, which in agreement with Persch et al. (in prep) who reported $12 \%$ of the root: shoot ratios for peat swamp in Jambi. In the oil palm plantation, we found root: shoot ratio was $28 \%$, which was very close to that of $30 \%$ for non-forest vegetation evaluated by Fearnside (2000). 
We compared our results with Murdiyarso's et al. (2009) study to estimate ecosystem C stocks of peat swamp forests at a landscape-scale from Tanjung Puting area. They reported smaller total ecosystem C stocks (894 $\pm 112 \mathrm{Mg} \mathrm{C} / \mathrm{ha})$ than our estimates $(1770 \pm 123 \mathrm{Mg} \mathrm{C} / \mathrm{ha})$ due to shallower organic soils in their study sites $(46 \pm 7 \mathrm{~cm})$. We calculated the total ecosystem $\mathrm{C}$ stocks of the primary peat swamp forests in Tanjung Puting were $1332 \pm 117 \mathrm{Mg} \mathrm{C} /$ ha (including 5 sites of primary forest from Murdiyarso's et al. (2009) and 2 sites of primary forest sites from our study). Using the difference of $174 \mathrm{Mg} \mathrm{C} /$ ha from the weighted average of 3 sampled sites of primary peat swamp forests and the mean of sampled oil palm plantations, we calculated an estimate of $640 \mathrm{Mg} \mathrm{CO}_{2} \mathrm{e} /$ ha are potentially lost due to primary peat swamp forest conversion to oil palm plantations due to vegetation loss. By combining all of the available data on ecosystem $\mathrm{C}$ stocks from peat swamp forests in Tanjung Puting, the results consistently show that the losses in $\mathrm{C}$ stocks were exceptionally high when peat swamp forest was converted to oil palm plantations.

This result can provide scientific evidence to improve regulations related to peat swamp forest conservation. For example, the Indonesia Presidential Decree No. 32/1990 and the Ministry of Agriculture Decree No. 14/2009 allow the use of Indonesian peatlands if peat thickness is less than $3 \mathrm{~m}$. These policies do not consider carbon emissions from the shallow peat swamp forest that may exceed the emissions from the deep peat swamp forest ecosystem. An improvement of Indonesia's peat map where currently estimated storing about $21.6 \mathrm{Gt} \mathrm{C}$ carbon stocks is also needed to reduce uncertainty and national peat carbon data (Warren et al. 2017).

\section{Conclusion}

This study provides robust scientific information for considerations of the role of peat swamp forest conservation in climate change mitigation strategies. The large carbon emissions resulting from their conversion clearly show the role of tropical peat swamp forests as the largest pools of soil organic carbon. Thus, avoiding deforestation from peat swamp forests should be regulated as a permanent policy instead of moratorium for a relatively short period of time. This is particularly important to achieve targeted or more ambitious national emission reduction as well as to measure the implementation progress agreed in Paris Agreement. Specifically stated in Article 6 of Paris Agreement that allows Indonesia to use carbon market as an international cooperation for climate change mitigation strategy.

Further, the European Union just enacts the Delegated Act in 2019 which is aimed to phase out palm oil as biofuel feedstock by 2030 since palm oil caused deforestation and conflict with food security (EU 2019). This is could be perceived as a good momentum for Indonesia to increase the research to intensify the yield of oil palm without land expansion and to utilize the degraded land instead of forest. By doing so, dual benefit might be attained, the economic incentives such as REDD+ incentive and eligible to export to EU for biofuel feedstock due to its effort on reducing deforestation and land degradation. In the end, avoiding peat forest conversion into 
palm oil might hamper the economic growth. Hence the solution is to intensify the yield of oil palm without land expansion or to develop palm oil on degraded dryland. These actions could bring double benefits: the economic incentives such as REDD+ incentive and eligible to export to EU for biofuel feedstock due to its effort on reducing deforestation and land degradation.

In this study, we have quantified ecosystem $C$ stocks of forests and oil palm plantations but have not examined the land-use transitions, including critical initial phases of land conversion entailing the losses associated with slash and burn. Future studies are needed to assess long-term chronosequences of ecosystem carbon dynamics associated with land use land cover change in the tropical peatlands.

Funding This study was possible through funding provided by the United States Agency for International Development (USAID) to the Center for International Forestry Research. This work was carried out as part of the Sustainable Wetland Adaptation and Mitigation Program (SWAMP).

\section{Literature Cited}

Adame MF, Santini NS, Tovilla C, Vázquez-Lule A, Castro L, Guevara M (2015) Carbon stocks and soil sequestration rates of tropical riverine wetlands. Biogeosciences 12:3805-3818

BSN [Badan Standardisasi Nasional] (2011) Pengukuran dan penghitungan cadangan karbonPengukuran lapangan untuk penaksiran cadangan karbon hutan (ground based forest carbon accounting). Indonesia

Basuki I (2017) Carbon stocks and emission factors of tropical peat swamp forests in respond to land cover changes in West Kalimantan, Indonesia. Dissertation. Oregon State University, Corvallis, Oregon, USA

Bhomia RK, van Lent J, Grandez-Rios JM, Hergoualc'h K, Honorio Coronado EN, Murdiyarso D (2019) Impacts of Mauritia flexuosa degradation on the carbon stocks of freshwater peatlands in the Pastaza-Maranon river basin of the Peruvian Amazon. Mitig Adapt Strateg Glob Change 24(4):645-668

Cairns MA, Brown S, Helmer EH, Baumgardner GA (1997) Root biomass allocation in the world's upland forests. Oecologia 111:1-11

Chao KJ, Phillips OL, Baker TR (2008) Wood density and stocks of coarse woody debris in a northwestern Amazonian landscape. Can J For Res 38:795-805

Chimner RA, Ewel KC (2005) A tropical freshwater wetland: II. Production, decomposition, and peat formation. Wetlands Ecol Manage 13:671-684

Corley RHV, Gray BS, Kee NS (1971) Productivity of the oil palm (Elaeis guineensis Jacq.) in Malaysia. Exp Agric 7:129-136

Davies SJ, Ashton PS (1999) Phenology and fecundity in 11 sympatric pioneer species of Macaranga (Euphorbiaceae) in Borneo. Am J Bot 86:1786-1795

Dommain R, Couwenberg J, Joosten H (2011) Development and carbon sequestration of tropical peat domes in south-east Asia: links to post-glacial sea-level changes and Holocene climate variability. Quatern Sci Rev 30(7-8):999-1010. https://doi.org/10.1016/j.quascirev.2011.01.018

Donato DC, Kauffman JB, Murdiyarso D, Kurnianto S, Stidham M, Kanninen M (2011) Mangroves among the most carbon-rich forests in the tropics. Nat Geosci 4:293-297

Draper FC, Roucoux KH, Lawson IT, Mitchard ET, Coronado ENH, Outi L, Montenegro LT, Sandoval EV, Baker TR (2014) The distribution and amount of carbon in the largest peat land complex in Amazonia. Environ Res Lett 9:124017 
EU (2019) Commision Delegated Act No 2055. Supplementing Directive (EU) 2018/2001 as regards the determination of high indirect land-use change- risk feedstock for which a significant expansion of the production area into land with high carbon stock is observed and the certification of low indirect land use change risk biofuels, bioliquids and biomass fuels

Farmer J, Matthews R, Smith P, Langan C, Hergoualc'h K, Verchot L, Smith JU (2014) Comparison of methods for quantifying soil carbon in tropical peats. Geoderma 214:177-183

Fearnside PM (2000) Global warming and tropical land-use change: greenhouse gas emissions from biomass burning, decomposition and soils in forest conversion, shifting cultivation and secondary vegetation. Clim Change 46:115-158

Gumbricht T, Roman-Cuesta RM, Verchot L, Herold M, Wittman F, Householder E, Herold N, Murdiyarso D (2017) An expert system model for mapping tropical wetlands and peatlands reveals South America as the largest contributor. Glob Change Biol 23:3581-3599

Henson IE (2003) The Malaysian national average oil palm: concept and evaluation. Oil Palm Bull $46: 15-27$

Hergoualc'h K, Carmenta R, Atmadja S, Martius C, Murdiyarso D, Purnomo H (2016) Managing peatlands in Indonesia: challenges and opportunities for local and global communities. CIFOR Infobrief no. 205

Hughes RF, Kauffman JB, Jaramillo VJ (1999) Biomass, carbon, and nutrient dynamics of secondary forests in a humid tropical region of Mexico. Ecology 80:1892-1907

Hughes RF, Kauffman JB, Jaramillo VJ (2000) Ecosystem-scale impacts of deforestation and land use in a humid tropical region of Mexico. Ecol Appl 10:515-527

Istomo (2002) Phosporus and calcium contents in the soil and biomass of peat swamp forest (A Case study at the concession area of PT. Diamond Raya Timber, Bagan Siapi-api, Riau Province). Dissertation. Bogor Agricultural University, Bogor, Indonesia.

Istomo C, Wibisono ITC (2009) Plant diversity and biomass content in relation to wise use of tropical peatland. In: Proceedings of the Bogor symposium and workshop on tropical Peatland management, Indonesia, 14-15 July

Jaenicke J, Rieley JO, Mott C, Kimman P, Siegert F (2008) Determination of the amount of carbon stored in Indonesian peatlands. Geoderma 147:151-158

Jourdan C, Rey H (1997) Modelling and simulation of the architecture and development of the oil-palm (Elaeis guineensis Jacq.) root system. Plant Soil 190:235-246

Kauffman JB, Heider C, Cole TG, Dwire KA, Donato D (2011) Ecosystem carbon stocks of Micronesian mangrove forests. Wetlands 31:343-352

Kauffman JB, Donato D (2012) Protocols for the measurement, monitoring and reporting of structure, biomass and carbon stocks in mangrove forests. Working Paper. Center for International Forestry Research (CIFOR), Bogor, Indonesia

Kauffman JB, Arifanti VB, Basuki I, Kurnianto S, Novita N, Murdiyarso M, Donato D, Warren MW (2016) Protocols for the measurement, monitoring, and reporting of structure, biomass and carbon stocks in tropical peat swamp forest. Working Paper. Center for International Forestry Research (CIFOR), Bogor, Indonesia

Kauffman JB, Trejo HH, Garcia MDCJ, Heider C, Contreras WM (2016) Carbon stocks of mangroves and losses arising from their conversion to cattle pastures in the Pantanos de Centla, Mexico. Wetlands Ecol Manage 24:203-216

Khasanah NM, van Noordwijk M, Ningsih H (2015) Aboveground carbon stocks in oil palm plantations and the threshold for carbon-neutral vegetation conversion on mineral soils. Cogent Environ Sci 1:1119964

Kho LK, Jepsen MR (2015) Carbon stock of oil palm plantations and tropical forests in Malaysia: a review. Singap J Trop Geogr 36:249-266

Krisnawati H, Adinugroho WC, Imanuddin R, Hutabarat S (2014) Estimation of forest biomass for quantifying $\mathrm{CO}_{2}$ emissions in Central Kalimantan: a comprehensive approach in determining forest carbon emission factors. Research and development center for conservation and rehabilitation. Forestry Research and Development Agency, Bogor, Indonesia 
Krisnawati HWC, Adinugroho R, Imanuddin (2012) The dynamic of aboveground carbon stock in peat swamp forest. Proceedings of international symposium on wild-fire and carbon management in peat forest in Indonesia, 13-14 Sept. Bogor, Indonesia

Langner A, Siegert F (2009) Spatiotemporal fire occurrence in Borneo over a period of 10 years. Glob Change Biol 15:48-62

Manuri SC, Brack NP, Nugroho K, Hergoualc'h N, Novita H, Dotzauer L, Verchot C, Agung S, Putra E, Widyasari (2014) Tree biomass equations for tropical peat swamp forest ecosystems in Indonesia. Forest Ecol Manag 334:241-253

Miettinen J, Shi C, Liew SC (2015) Land cover distribution in the peatldns of Peninsular Malaysia, Sumatra and Borneo in 2015 with changes since 1990. Glob Ecol Conserv 6:67:68

Ministry of Environment and Forestry (2015) Tanjung Puting national park. https://tanjungputing. dephut.go.id/index.php/tentang-kawasan/letak-dan-luas. Retrieved 6 Jan 2015

Murdiyarso D, Donato D, Kauffman JB, Kurnianto S, Stidham M, Kanninen M (2009) Carbon storage in mangrove and peatland ecosystems: a preliminary account from plots in Indonesia. Working Paper 48. Center for International Forestry Research (CIFOR), Bogor, Indonesia

Málaga N, Hergoualc'h K, Kapp G, Martius C (2020) Variation in vegetation and ecosystem carbon stock due to the conversion of disturbed forest to oil palm plantation in Peruvian Amazonia. Ecosystems 1-19

Ng SK, Thamboo S, de Souza P (1968) Nutrient contents of oil palms in Malaysia. II. Nutrients in vegetative tissues. Malaysia Agric J 46:332-391

Novita N (2010) Above ground biomass of logged-over forests in Merang, South Sumatra. Thesis. Graduate School. Bogor Agricultural University. Bogor, Indonesia

Noway Government (2019) News: https://www.norway.no/en/indonesia/norway-indonesia/newsevents/news $2 /$ indonesia-reports-reduced-deforestation-triggering-first-carbon-payment-fromnorway/

Page SE, Rieley JO, Banks CJ (2011) Global and regional importance of the tropical peatland carbon pool. Glob Change Biol 17:798-818

Persch S, Hergoualc'h K, Hölscher D, Verchot L (In prep) Large above- and below-ground biomass carbon losses from a tropical peat swamp forest transition into an oil palm plantation: a case study in Sumatra, Indonesia

Page SE, Rieley JO, Wüst R (2006) Lowland tropical peatlands of Southeast Asia. Peatlands: evolution and records of environmental and climate changes. Elsevier

Posa MRC, Wijedasa LS, Corlett RT (2011) Biodiversity and conservation of tropical peat swamp forests. Bioscience 61:49-57

Saharjo BH (2007) Shifting cultivation in peatlands. Mitig Adapt Strat Glob Change 12:135-146

Sheehan PJ (1984) Effects on community and ecosystem structure and dynamics. Effects of pollutants at the ecosystem level. Wiley

Simbolon H (2015) Above ground biomass changes in the peat swamp forests of Central Kalimantan https://www.forestday.org/fileadmin/tropical-workshop/Plenary-3/17A_Sim bolonH_Above\%20ground\%20biomass.pdf. Accessed 13 July 2015

Syahrinudin (2005) The potential of oil palm and forest plantations for carbon sequestration on degraded land in Indonesia. Dissertation. University of Goettingen, Germany

Warren MW, Kauffman JB, Murdiyarso M, Anshari G, Hergoualc'h K, Kurnianto S, Purbopuspito J, Gusmayanti E, Afifudin M, Rahajoe J, Alhamd L, Limin S, Iswandi A (2012) A cost-efficient method to assess carbon stocks in tropical peat soil. Biogeosciences 9:4477-4485

Warren M, Hergoualc'h K, Kauffman B, Murdiyarso D, Kolka R (2017) An appraisal of Indonesia's immense peat carbon stock using national peatland maps: uncertainties and potential losses from conversion. Carbon Balance Manage 12:12

Weiss D, Shotyk W, Rieley J, Page S, Gloor M, Reese S, Martinez-Cortizas A (2002) The geochemistry of major and selected trace elements in a forested peat bog, Kalimantan, SE Asia, and its implications for past atmospheric dust deposition. Geochim Cosmochim Acta 66:2307-2323 
Wösten JHM, Van Den Berg J, Van Eijk P, Gevers GJM, Giesen WBJT, Hooijer A, Idris A, Leenman PH, Rais DS, Siderius C, Silvius MJ (2006) Interrelationships between hydrology and ecology in fire degraded tropical peat swamp forests. Water Resour Develop 22:157-174

Yu Z, Beilman DW, Frolking S, MacDonald GM, Roulet NT, Camill P, Charman DJ (2011) Peatlands and their role in the global carbon cycle. EOS 92: 97-108.

Open Access This chapter is licensed under the terms of the Creative Commons Attribution 4.0 International License (http://creativecommons.org/licenses/by/4.0/), which permits use, sharing, adaptation, distribution and reproduction in any medium or format, as long as you give appropriate credit to the original author(s) and the source, provide a link to the Creative Commons license and indicate if changes were made.

The images or other third party material in this chapter are included in the chapter's Creative Commons license, unless indicated otherwise in a credit line to the material. If material is not included in the chapter's Creative Commons license and your intended use is not permitted by statutory regulation or exceeds the permitted use, you will need to obtain permission directly from the copyright holder. 